\title{
Menneske-datamaskine interaktion i informationssøgesystemer: evaluering af brugs- og lasevenlighed
}

\author{
Af Kasper Hornbæk
}

Informationss $\emptyset$ gesystemer siger $\bmod$ at st $\emptyset$ tte mennesker i at søge efter, læse og på anden måde håndtere information. $\mathrm{Ud}$ fra min baggrund i fagfeltet menneske-datamaskine interaktion argumenterer jeg for at brugs- og læsevenlighed er nyttige evalueringskriterier for informationss $\emptyset$ gesystemer. Denne argumentation er i overensstemmelse med en stigende interesse $i$ fagfeltet informationssøgning for brugergrænseflader og for menneske-datamaskine interaktion. For at illustrere nytten af at fokusere på brugs- og læsevenlighed giver jeg to eksempler på evaluering af informationssøgesystemer som jeg har været med til at udvikle. Målet med brugergrænsefladerne til disse informationss $\varnothing$ gesystemer er at st $\varnothing$ tte brugsog læsevenlighed. Eksemplerne illustrerer hvordan vi i menneske-datamaskine interaktion arbejder med evaluering. De viser også hvordan tætte studier af interaktionen mellem mennesker og datamaskiner kan bruges til at forstå gode og dårlige egenskaber ved informationss $\varnothing$ gesystemer.

Først i artiklen vil jeg beskrive hvad menneskedatamaskine interaktion handler om. Desuden beskriver jeg min opfattelse af hvordan fagfelteterne menneske-datamaskine interaktion og informationss $\emptyset$ gning $\mathrm{kan}$ inspirere hinanden. Afsnittet 'Brugsvenlighed og lasevenlighed' viser hvordan brugs- og læsevenlighed kan måles i forbindelse med evaluering. De to næste afsnit i artiklen, 'Tematiske kort' og 'Visualisering af dokumenter', beskriver eksemplerne på evaluering af brugergrænsefladers brugs- og læsevenlighed. Det sidste afsnit $i$ artiklen opsummerer nytten af fokus på menneske-datamaskine interaktion ved evaluering af informationss $\varnothing$ gesystemer.

\section{Menneske-datamaskine interaktion og informati- onssogning}

I menneske-datamaskine interaktion arbejder vi med design, evaluering og implementering af interaktive edb-systemer. Særligt prøver vi at forstå de fænomener som omgiver og former menneskers brug af edb-systemer. Fremkomsten af den personlige computer og den stigende brug af datamater $\mathrm{i}$ mange menneskers arbejde og fritid blandt andet $\mathrm{i}$ form af World Wide Web (WWW) - har gjort udvikling af velegnede brugergrænseflader og studier af menneske-datamaskine interaktion nødvendig. På den baggrund er menneskedatamaskine interaktion vokset som fagfelt og har nu årlige konferencer (for eksempel ACMs konference om Computer-Human Interaction) og flere solide introducerende bøger (for eksempel Shneiderman, 1998).

I menneske-datamaskine interaktion har der fra 1980 erne været en udbredt interesse for informationss $\varnothing$ gning. Der bliver i stadig stigende omfang udviklet innovative grænseflader til informations- 
søgning som f.eks. støtter formulering af forespørgsler (Young \& Shneiderman, 1993) og forståelse af søgeresultater (Hearst, 1995) eller som giver et overblik over dokumentsamlinger (Chen et al., 1998). Mit eget arbejde i menneske-datamaskine interaktion har været koncentreret om problemer i informationssøgning, blandt andet fordi disse problemer er psykologisk og teknisk komplekse og fordi de kan genkendes fra mit eget arbejde. En anden motivation er, at jeg mener at mange informationss $\varnothing$ gesystemer kan forbedres afgørende, f.eks. ved hjælp af grafiske brugergrænseflader.

I feltet informationssøgning er der tilsvarende en stigende interesse for brugergrænseflader og menneske-datamaskine interaktion. For eksempel har Marchionini \& Komlodi (1998) vist at ordene 'user interface' i databaserne Library and Information Science Abstracts og Information Science Abstracts forekommer i dobbelt så mange resumeer af dokumenter i 1996 som i 1986. Jeg tror denne stigende interesse skyldes tre ting:

1) I informationss $\varnothing$ gning er der en stigende kritik af de kriterier for søgeeffektivitet som hyppigst anvendes i evaluering af informationss $\emptyset$ gesystemer, precision og recall, se f.eks. Hersh (1994). Det er blevet klart at disse evalueringskriterier kun i begrænset omfang er relateret til den egentlige nytte og brugbarhed af informationss $\emptyset$ gesystemer. Marchionini (1992), s. 156, har udtrykt det således:

'End users want to solve their information problems; they want to do their work or accomplish their goal. They want answers rather than pointers; they want document delivery rather than information retrieval. End users do not care about the design of the information system, the elegance of the retrieval engine, or the structure of the data unless these severely impede the accomplishments of their goals.'

Derfor er det vigtigt at finde evalueringsmetoder og evalueringskriterier som er relateret til hvor godt brugerne løser deres opgaver, og ikke kun hvor godt systemet fremfinder dokumenter. Alternativer til performancemålene recall og precision, såsom kvaliteten af de opgaver der løses ved brug af informations- søgesystemet og brugernes tilfredshed med systemet, har i mange år været anvendt i menneske-datamaskine interaktion. Menneskedatamaskine interaktion har også $\mathrm{i}$ vid udstrækning brugt metoder som inddrager brugere i evaluering af brugergrænseflader.

2) For det andet er det i stigende omfang klart at brugergrænsefladens udformning er kritisk afg $\emptyset$ rende for udfaldet af informationss $\varnothing$ gning. Susan Dumais (1996) har påpeget at mens algoritmer til søgemaskiner ofte giver forbedringer fra $1-10 \%$ i målbare evalueringskriterier, så forbedrer veldesignede brugergrænseflader informationss $\varnothing$ gning med op til $25 \%$. Kun systemer til relevans-feedback kan opnå tilsvarende forbedringer. Denne udtalelse er særlig bemærkelsesværdi fordi Dumais i mange år har forsket i netop algoritmer til informationss $\varnothing g$ systemer. Veldesignede brugergrænseflader og solide evalueringer af disse er derfor vigtige.

3) Endelig søger brugere uden særlige kundskaber om søgemaskiner, forespørgselssprog og katalogiseringsprincipper stadig hyppigere information, f.eks. på WWW. Dette stiller krav til informationss $\varnothing$ gesystemer om at st $\varnothing$ tte novicer i at søge, og at gøre det nemt at formulere forespørgsler og forstå resultaterne af søgninger. Menneske-datamaskine interaktion tilbyder teknikker som forbedrer disse dele af en brugergrænseflade.

\section{Brugs- og lasevenlighed}

I menneske-datamaskine interaktion er brugs- og læsevenlighed afgørende ved design og evaluering af informationssøgesystemer. Brugsvenlighed er det væsentligste begreb fra menneske-datamaskine interaktion $\mathrm{i}$ forbindelse med evaluering af informationssøgesystmer. Der findes en række forskellige forslag om hvad brugsvenlighed omfatter og hvordan man måler brugsvenlighed, se f.eks. Shneiderman (1998). Disse forslag omfatter den tid det tager at lære at bruge systemet, hvor nemt det er at huske hvordan systemet bruges, den tid det tager at løse bestemte opgaver, nytten af systemet og brugernes tilfredshed med systemet. ISO (1998) har foreslået en standard for brugsvenlighed som omfatter tre aspekter. 
1) Effektivitet, det vil sige hvor præcist og komplet brugeren når sine mål. Effektivitet kan måles f.eks. som kvaliteten af løsning på de opgaver som er blevet støttet af informationssøgesystemet.

2) Produktivitet, som er forholdet mellem effektivitet og de ressourcer som brugeren anvender for at nå sine mål. Produktivitet vil ofte være udtrykt som f.eks. den tid det tager at løse en opgave med systemet eller den mentale belastning ved løsning af opgaver.

3) Tilfredshed, som er brugerens holdning til og komfort ved brugen af systemet. Brugernes tilfredshed vil ofte blive målt ved åbne spørgsmål som stilles efter brug af systemet eller med spørgeskemaer dedikerede til måling af tilfredshed, f.eks. Questionnaire for User Interaction Satisfaction (Chin, Diehl \& Norman, 1988).

Sammen med Erik Frøkjær og Morten Hertzum har jeg argumenteret for at alle tre aspekter af brugsvenlighed skal måles ved evaluering (Frøkjær, Hertzum \& Hornbæk, 2000). Vi viste at man ikke kan antage at de tre aspekter hænger sammen, f.eks. er produktive systemer ikke nødvendigvis effektive. Derfor bør man måle alle tre aspekter.

Systemer til informationss $\emptyset$ gning bør tillige st $\varnothing t t e$ loesevenlighed. Dette er en konsekvens af at dokumenter, web-sider og e-post i stigende grad læses direkte fra skærmen. For eksempel har Sellen \& Harper (1997) beskrevet brugen af papir og elektroniske dokumenter hos analytikere i International Monetary Fund. Sellen \& Harper anslår at $14 \%$ af tiden analytikerne arbejdede med dokumenter læser de dem fra skærmen. Analytikerne brugte en kombination af skærmlæsning og papirlæsning $35 \%$ af tiden. Et studie af brugen af WWW (Byrne et al., 1999) viste at brugere benytter dobbelt så lang tid på at bruge den information de finder ved søgning, browsing og andre aktiviteter. Læsning fra skærmen udgør den vigtigste måde at bruge information på. I menneskedatamaskine interaktion, $\mathrm{i}$ pædagogisk orienterede undersøgelser af læsning og i teknikker til effektiv udformning af dokumenter er der forsket intenst $\mathrm{i}$ hvordan en brugergrænseflade kan støtte læsevenlighed (Dillon, 1994; Schriver, 1997). Denne litteratur beskriver teknikker til at forbedre navigation i dokumenter, til at gøre læsning fra skærmen mere behagelig og til at hjælpe brugere med bedre at huske en tekst. Det er muligt at forbedre læsevenligheden uden at ændre indholdet af dokumenterne $i$ et informationss $\varnothing$ gesystem, f.eks. ved at sikre at skrifttyperne er læselige, at linierne i dokumentet ikke er for lange og ved at tilbyde et overblik over dokumenter. Når brugere læser direkte fra skærmen bliver løsningen af det problem som ledte til informationssøgning afhængig af, hvor godt systemet st $\varnothing$ tter læsning. Læsevenlighed er derved en forudsætning for brugsvenlighed og kan måles indirekte ved at se på brugsvenligheden af et system. Læsevenlighed kan også evalueres direkte ved at se på hvordan brugerne navigerer i dokumenter, hvordan de læser dokumenter, hvor meget de lærer af at læse teksten, samt ved at undersøge deres tilfredshed med læsningen. Desværre er læsevenlighed ikke hyppigt i fokus ved evaluering af systemer til informationss $\emptyset \mathrm{g}$ ning (undtagelser findes, f.eks. Kengeri et al., 1999). Det undrer mig at forskning i informationssøgning i 50 år har fokuseret på at støtte fremfinding af dokumenter, uden dog at st $\varnothing$ tte brugere i bekvemt og effektivt at læse disse dokumenter fra en skærm.

I de følgende to afsnit giver jeg eksempler på hvordan evalueringer af systemer til informationssøgning og -håndtering kan foregå ud fra et fokus på brugsvenlighed og læsevenlighed.

\section{Tematiske kort}

Tematiske kort er blevet foreslået som en måde at forbedre informationss $\emptyset$ gning på. Et tematisk kort viser et grafisk overblik over en samling af dokumenter sammen med ord som beskriver temaerne i dokumentsamlingen, se figur 2. Forhåbningen til tematiske kort er at de forbedrer brugsvenligheden i forhold til ikke-grafiske systemer. Det tematiske kort antages at hjælpe brugere til at overskue en dokumentsamling, at være behageligt at søge på og at være hurtigt, fordi brugere kan søge ved hjælp af den visuelle repræsentation af dokumenter og temaer. For at unders $\varnothing$ ge om disse forhåbninger kunne indfries sammenlignede vi et 
tekstbaseret informationss $\emptyset$ gesystem med et tematisk kort. Både det tekstbaserede system og det tematiske kort tillod fors $\varnothing$ gspersonerne at formulere forespørgsler og at se fuldtekst af dokumenterne i samlingen. Den visuelle repræsentation af dokumenter og temaer er dermed den eneste forskel mellem systemerne og derfor den eneste kilde til forskelle i brugsvenlighed. Undersøgelsen er yderligere beskrevet i Hornbæk \& Frøkjær (1999).

\section{Unders $\varnothing$ gelsens opbygning}

I unders $\emptyset$ gelsen løste seks fors $\emptyset$ gsdeltagere hver otte opgaver, fire opgaver med hver af de to grænseflader. Halvdelen af opgaverne beskrev ét dokument som forsøgspersonerne skulle finde i dokumentsamlingen, f.eks. 'Find artiklen af Rudolf Darken om hvordan man navigerer virtuelle verdener'. Den anden halvdel af opgaverne skulle besvares med en gruppe af dokumenter, f.eks. 'Forestil dig at du skal holde et foredrag om brug af computere i undervisning. Hvad findes der $i$ systemet om dette emne?' Dokumentsamlingen som fors $\emptyset$ gspersonerne søgte i indeholdt omkring 500 fuldtekstartikler fra konferencer om menne- ske-datamaskine interaktion. Unders $\varnothing$ gelsen blev

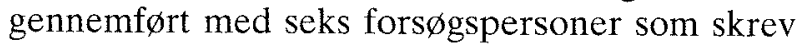
speciale i datalogi og som kendte til menneskedatamaskine interaktion. Under eksperimentet blev forespørgsler, læsning af dokumenternes fuldtekst $\mathrm{g}$ brug af det tematiske kort automatisk registreret. Efter fors $\varnothing$ get var det derfor muligt at rekonstruere $s \emptyset$ gningerne. Fors $\varnothing$ gspersonerne blev opfordret til at tænke højt mens de løste opgaverne. Tænke-højt teknikker er almindeligt anvendt i $\mathrm{HCI}$ og går ud på at få forsøgspersoner til hele tiden at fortælle hvad de tænker, se Helms Jørgensen (1990). Forsøgspersonerne ytringer blev optaget på bånd.

\section{Tekstbaseret informationssøgesystem og tematisk kort \\ Det tekstbaserede informationssøgesystem er vist i figur 1. Øverst i vinduet kan brugeren formulere forespørgsler med boolske operatorer. Resultatet af forespørgsler vises som en liste af titler og for- fattere nederst i vinduet. Fuldteksten af doku- menter i listen kan ses ved at dobbeltklikke med musen på en titel.}

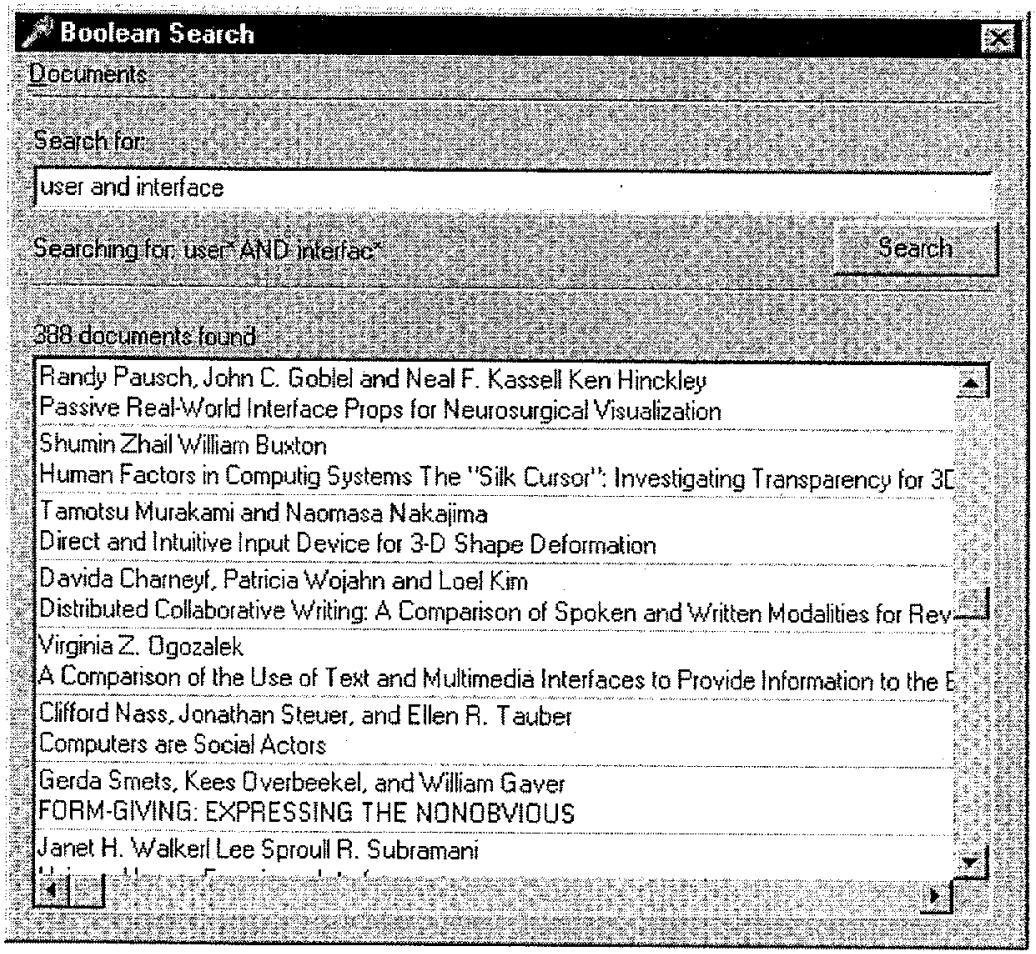

Figur 1. Tekstbaseret informationssøgesystem. 
Det tematiske kort er vist i figur 2. I feltet $\varnothing v e r s t$ på skærmen kan indtastes forespørgsler og listen til højre viser fremfundne dokumenter. Disse dele af grænsefladen svarer til den $\varnothing$ verste og nederste del af det tekstbaserede informationss $\varnothing$ gesystem. Til venstre findes selve det tematiske kort med dokumenter og ord som beskriver temaer på kortet. Dokumenter er vist som sorte og lyse prikker. Dokumenterne der er blevet fremfundet ved søgning efter ordene 'user' og 'interface' er i figuren markeret med en lys prik på kortet. De sorte prikker er dokumenter som ikke indeholder ordene 'user' og 'interface'.

Det tematiske kort er konstrueret ved brug af multidimensionel skalering (Borg \& Groenen, 1997). Algoritmen til multidimensionel skalering placerer dokumenterne i dokumentsamlingen i to dimensioner ved brug af cosinus-målet for lighed mellem dokumenter - et almindeligt benyttet lighedsmål i søgemaskiner (Salton \& McGill, 1983). Placeringen af dokumenter på kortet sigter mod at minimere forskellen mellem cosinus-ligheder mellem dokumenter og afstande mellem dokumenterne på kortet. Udover dokumenterne viser det tematiske kort også ord som beskriver temaerne i dokumenterne. De ord som bliver vist på kortet er de ord i dokumentsamlingen med højest diskriminationsværdi (Salton \& McGill, 1983). Intuitivt er ord med høj diskriminationsværdi hyppigt forekommende i nogle dokumenter og sjældent $i$ andre, for eksempel ordet 'evaluation' i den brugte dokumentsamling. Disse ord blev placeret på massemidtpunktet mellem dokumenter som de forekommer i og beskriver derved temaerne i det område af kortet de er placeret $i$.

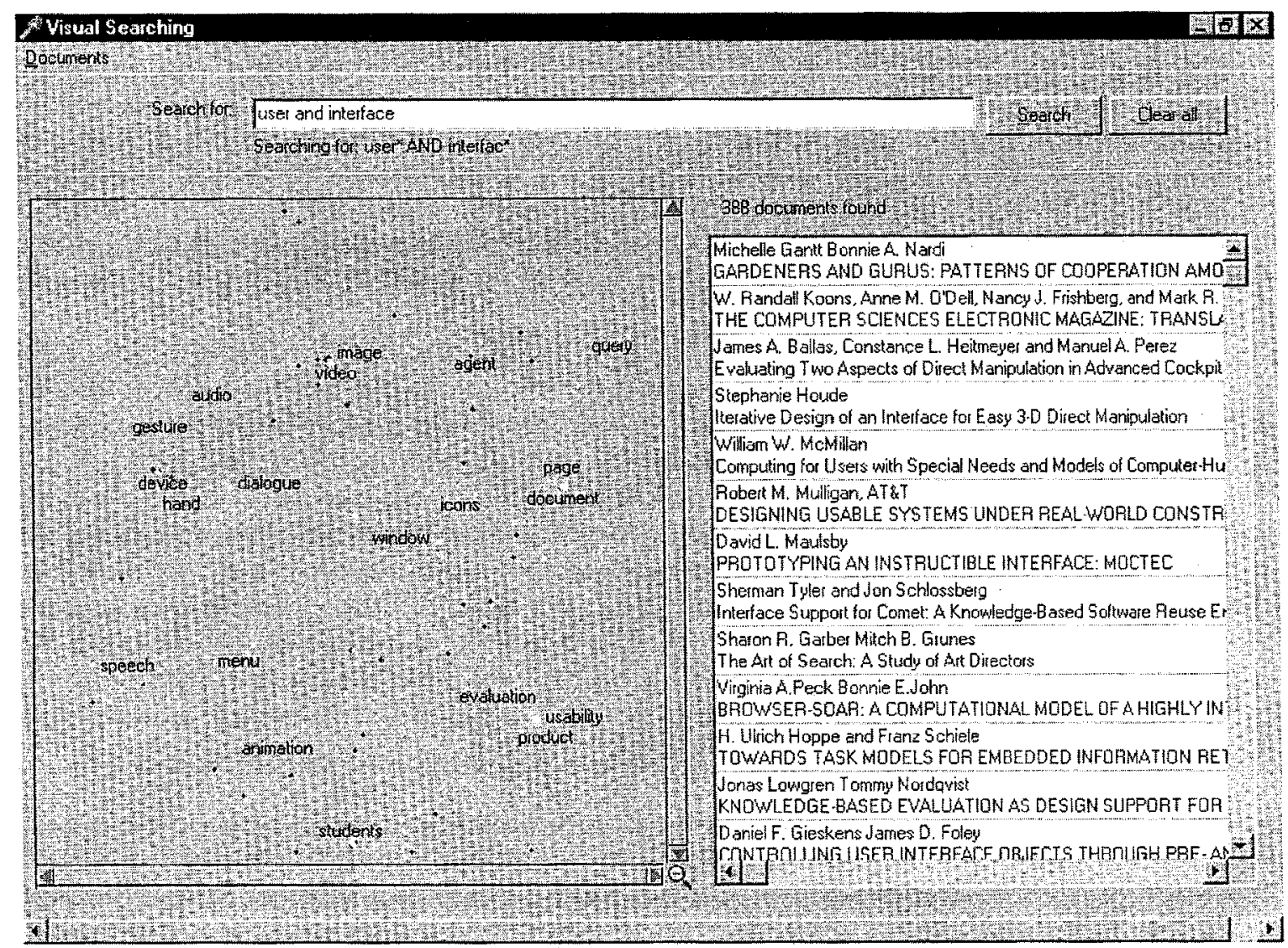

Figur 2 - Tematisk kort 
Forespørgsler, listen over dokumenter og det tematiske kort er knyttet sammen på flere måder. Ud over at alle dokumenter på kortet som er fremfundet som svar på en forespørgsel farves gule, indikeres forespørgselstermer også visuelt på kortet. Når brugeren vælger et dokument på listen med fremfundne dokumenter, markeres dette dokuments position på kortet. Dokumenternes titler og forfattere vises når musen holdes over et dokument på kortet, ligesom fuldtekst kan bringes frem fra kortet ved hjælp af en pop-up menu. Det er muligt at zoome ind på en del af kortet hvorved der fremkommer flere ord på kortet som beskriver temaer.

\section{Forskelle i brugsvenlighed}

Brugsvenligheden af de to grænseflader blev målt som antallet af dokumenter fors $\varnothing$ gspersonerne fandt relevante, deres tidsforbrug og deres tilfredshed med systemet. Den statistiske analyse benyttede variansanalyse og parvise t-tests og er beskrevet nærmere i Hornbæk \& Frøkjær (1999). Dertil har vi en række kvalitative observationer som belyser hvordan fors $\emptyset$ gspersonerne bruger kortet. Vi fandt ingen statistisk signifikant forskel mellem de to grænseflader i antallet af dokumenter som fors $\varnothing$ gspersonerne markerede som relevante og som vi også fandt relevante (dvs. interaktiv recall). Antallet af dokumenter som mere end en person fandt relevant var heller ikke væsentlig forskelligt mellem grænsefladerne. Til gengæld fandt vi en overraskende forskel i tidsforbrug mellem de to grænseflader. Fors $\varnothing$ gspersonerne brugte 14.2 minutter per opgave med den visuelle grænseflade og blot cirka 10.8 minutter med den boolske grænseflade. Vores egne og gængse hypoteser om nytten af tematiske kort kan derved ikke indfries i dette studie. Tematiske kort ser altså ikke ud til at $g \varnothing r e$ informationss $\varnothing$ gere mere produktive. Efter at have løst opgaverne interviewede vi forsøgspersonerne om deres tilfredshed med de to grænseflader. Fire ud af de seks forsøgspersoner foretrak at bruge det tematiske kort. De synes at grafikken var behagelig, de kunne lide det overblik man fik fra det tematiske kort og de blev inspireret til at finde søgeord ved at kigge på kortet. En af forsøgspersonerne sagde:

"Jeg kunne bedre lide det grafiske, det var lidt sjovere på en eller anden måde. Det er nok det bedste ved [det tematiske kort]" og en anden sagde:

"Dels havde man ordene [på kortet] og så kunne man også se hvor mange [dokumenter] man havde ramt sådan nogenlunde, så man kunne hurtigere danne sig et overblik over hvordan ens søgning gik, om man havde ramt mange eller få, også hvordan de lå placeret i forhold til hinanden, om de var tæt på eller spredt."

I interviewet efter forsøget nævnte halvdelen af fors $\emptyset$ gspersonerne at de til tider havde problemer med at forstå kortet. For eksempel var forholdet mellem ord og dokumenter på kortet uklart for nogle af forsøgspersonerne. En af dem næunte:

"Jeg undrer mig lidt over de kategorier [ord på kortet] som er vist, det er lidt ... nogle af dem er hovedtemaer i datalogien ligesom 'evaluation' og 'usability' som man kan forholde sig til men sådan noget som 'hand'... det kan betyde hvad som helst"

og en anden:

"Det var lidt uklart hvad det [kortet] egentlig betød. Jeg fik ikke nogen fornemmelse af en struktur eller gruppering. Lidt abstrakt hvad det betyder med nogle prikker rundt omkring."

Flere fors $\emptyset$ gspersoner udtrykte også overraskelse når de så på dokumenter ved siden af hinanden på kortet og ikke kunne afgøre hvad dokumenterne havde tilfælles. En fors øgsperson kommenterede

"Man håber at når dokumenterne er tæt på hinanden så handler de om det samme".

Da jeg spurgte forsøgspersonen hvor tit dokumenterne handlede om det samme sagde vedkommende:

"Måske halvdelen af gangene."

Tilfredsheden med det tematiske kort er derved blandet, med positive kommentarer om oplevelsen af at søge men også væsentlige problemer med kortets forståelighed og gennemskuelighed.

De kvalitative observationer om brugen af kortet vedrører forsøgspersonernes inspiration til søge- 
ord og hvordan forsøgspersonerne søgte på kortet. Ved at analysere fors $\emptyset$ gspersonernes ytringer fra eksperimentet fandt vi fire kilder som inspirerede fors $\varnothing$ gspersonernes valg af søgeord: 1) inspiration fra teksten som beskriver opgaven, 2) inspiration fra associationer eller anden inspiration som ikke. kan detekteres i tænke-højt ytringerne, 3) inspiration fra dokumenternes fuldtekst eller titler og 4) inspiration fra ord på det tematiske kort. Med denne klassifikation viser det sig at cir$\mathrm{ka}$ halvdelen af søgeordene kommer fra beskrivelsen af opgaven, cirka en tredjedel fra associationer og cirka ti procent fra enten dokumenters fuldtekst eller det tematiske kort. Typisk sker inspirationen til søgeord fra det tematiske kort ved at fors øgspersonen ser et ord på kortet og derefter bruger det i en forespørgsel. Fors $\varnothing$ gspersonerne foretrak at søge på kortet frem for at skimme listen af titler og forfattere. Fors $\varnothing$ gspersonerne begyndte en tredjedel af alle opgaver med at s $\varnothing \mathrm{ge}$ på kortet; i resten af opgaverne begyndte fors $\varnothing$ gspersonerne med en forespørgsel men derefter søgte de på kortet. Søgning på kortet skete typisk på tre måder. For det første fokuserede nogle forsøgspersoner på bestemte ord eller områder på kortet. I en opgave om lyd i brugergrænseflader bemærkede en fors $\emptyset$ gsperson for eksempel:

"Ja, grænseflader der anvender lyd, så var det jo at der lå, hvad var det jeg fandt der hed noget her 'audio', 'speech' på kortet, netop fordi det sådan er et søgeord der, tror jeg jeg vil gå ind og kigge om der er noget [på kortet]"

Nogle forsøgspersoner fokuserede også på et bestemt område på kortet, f.eks. opdagede en person et område med mange dokumenter fremfundet i relation til en forespørgsel og sagde:

"Jeg prøver lige at se på den sky der over [på kortet], for at se hvorfor den er placeret der ovre".

For det andet var der opgaver hvor forsøgspersonerne brugte et dokuments position på kortet til at vurdere om dokumentet var relevant. Fors $\varnothing$ gspersonerne brugte også et dokuments position til at finde andre relevante dokumenter:

"Hmm, ja det er jo, altså jeg ville jo umiddelbart sige at det er sikkert også relevant fordi den ligger i nærheden af de andre [fremfundne dokumenter]".

For det tredje søgte nogle af fors $\emptyset g s p e r s o n e r n e$ målløst på det tematiske kort. Vi observerede primært dette i søgninger efter velspecificerede dokumenter, hvor nogle fors $\varnothing$ gspersoner - når de ikke nemt kunne finde et dokument som besvarede opgaven - kiggede mange gange på de sammẻ dokumenter og områder på kortet.

Konklusion på undersøgelsen af tematiske kort Undersøgelsens hypotese om at en visuel grænseflade forbedrer brugsvenligheden af informationss $\emptyset$ gning blev ikke entydigt bekræftet. Fors $\emptyset$ gspersoner var langsomme med det tematiske kort end med den boolske grænseflade. Omvendt viser interviewene med forsøgspersonerne at de kunne lide at $s \varnothing g e$ på kortet. Analysen af tænke-højt ytringerne viser at de fandt nyttige søgeord på kortet. Interaktionen med kortet er omfattende og er blandt andet rettet mod at prøve at afg øre dokumenters relevans ud fra deres position på kortet og mod at finde interessante ord og områder på kortet. Hvorfor er brugsvenligheden så ikke højere for det tematiske kort? En forklaring er at fors $\emptyset$ gspersonerne taber fokus på deres s $\varnothing g e-$ opgave, fordi de skifter meget mellem forespørgsler og at skimme kortet. Til tider distraheres de måske også af det tematiske kort og begynder at søge målløst på kortet. Desuden er forståelighed-. en af det automatisk genererede kort problemfyldt.

En klar forbedring af det tematiske kort ville være bedre algoritmer til at vælge de ord som karakteriserer temaer, f.eks. kunne man give mere kontekst end et enkelt ord ved at bruge kombinationer af ord eller sætninger. Dertil bør forståeligheden af kortet forbedres generelt, f.eks. ved at gøre det eksplicit hvilke temaer dokumenter tæt på hinanden har tilfælles. Desuden er det svært at foretage en systematisk afs $\emptyset$ gning af fremfundne dokumenter på kortet: flere fors $\emptyset$ gspersoner foreslog at en mere håndterbar, lineær struktur ville være et nyttigt supplement til kortets associative struktur. 


\section{Visualisering af dokumenter}

Litteraturen om menneske-datamaskine foreslår adskillige brugergrænseflader som visualiserer dokumenter, se f.eks. Card et al. (1999). Intentionen med disse brugergrænseflader er at støtte læsning og navigation i dokumenter ved at vise dokumenternes struktur eller ved visuelt at fremhæve vigtige dele af dokumentet og nedtone andre dele. Brugs- og læsevenligheden af de foreslåede grænseflader er dog kun i et par tilfælde blevet unders $\emptyset \mathrm{gt}$. Disse unders $\emptyset \mathrm{gelser}$ har ikke kunnet vise at visualisering giver højere brugsvenlighed. Derfor gennemførte jeg sammen med Erik Frøkjær et eksperiment hvor 20 fors $\varnothing g s p e r s o n e r$ læste artikler med en lineær-, en fiskeøje- og en overbliksgrænseflade (se figur 3). Artiklerne handlede om objekt-orienteret systemudvikling. $\mathrm{Vi} \emptyset$ nskede at undersøge forskelle i brugsvenlighed mellem brugergrænsefladerne. Til det formål så vi på karakterer givet til forsøgspersonernes svar på opgaver vi gav dem, på forsøgspersonernes tilfredshed og på interaktionen med grænsefladerne. Desuden ville vi gerne undersøge læsevenlighed og beskrive hvordan forskellige brugergrænseflader påvirker læseprocessen. Eksperimentet er yderligere beskrevet i Hornbæk \& Frøkjær (2001).

\section{Brugergronseflader}

Figur 3 viser skærmbilleder af de tre brugergrænseflader som vi undersøgte i eksperimentet. I alle grænsefladerne kan musen og tastaturet bruges til at navigere med. Den lineære grænseflade (nederst i figur 3) viser dokumenter på samme måde som de fleste tekstbehandlingsprogrammer og WWW-browsere. Hensigten med denne grænseflade er at etablere et sammenligningsgrundlag for de to andre grænseflader. Fiskeøjegrænsefladen (midterst i figur 3) behandler nogle dele af et dokument som mere vigtige end andre. Fiskeøjegrænseflader fungerer på samme måde som et fiskeøjeobjektiv til et kamera, ved at forstørre de centrale/vigtige dele af motivet mens de perifere dele vises uforholdsmæssigt små. I brugergrænsefladen brugt $\mathrm{i}$ eksperimentet er de vigtige dele af et dokument altid læsbare. De øvrige dele af dokumentet er formindsket, men kan udvides til læselig størrelse ved at klikke på dem med musen. De vigtige dele af en artikel bestemmes på to måder. For det første viser forskning i automatisk sammenfatning af dokumenter at de første og sidste dele af et afsnit er gode indikatorer for afsnittets indhold (Bradow, Mitze \& Rau, 1995). Vi brugte denne ide på alle sektioner i dokumentet, så de midterste dele af alle afsnit var formindskede. For det andet lægger læsere af videnskabelige
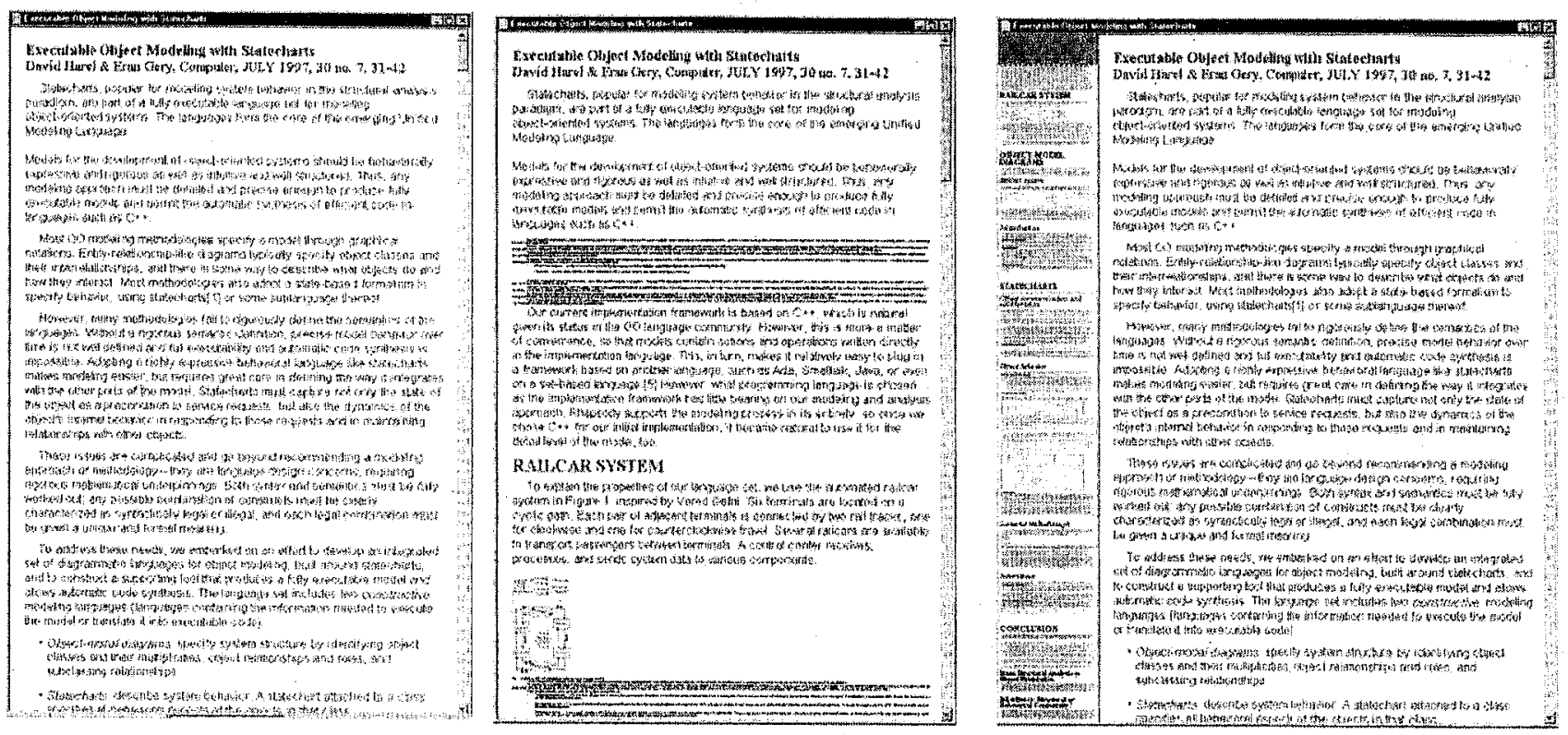

Figur 3. Græenseflader som visualiserer dokumenter. 
dokumenter særligt mærke til resumeet, overskrifter og så videre (Dillon, 1994; Bishop, 1999). Derfor kan man i fiskeøjegrænsefladen altid læse disse dele af dokumenterne. Hensigten med fiskeøjegrænsefladen er, at reducere den tid der bruges på at navigere i dokumentet ved at gøre dokumentet kortere - i gennemsnit er dokumenterne $25 \%$ kortere i fiskeøjegrænsefladen. Desuden ville vi

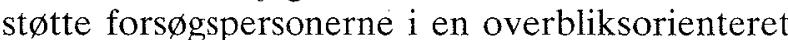
læsestrategi, hvor de først læser de vigtigste afsnit $i$ et dokument og senere kan læse detaljerne. I højre del af overbliksgrænsefladen ( $\varnothing$ verst i figur 3 ) detaljeområdet - er dokumentet vist på samme måde som i den lineære grænseflade. Dertil er knyttet et overblik over dokumentet - overbliksområdet - som viser en kompakt version af dokumentet, hvor overskrifter i dokumentet er synlige.

Overbliksområdet indikerer ved en mørk firkant hvilken del af dokumentet der er vist i detaljeområdet. Det er muligt at bruge overbliksområdet til at navigere i artiklen, f.eks. ved at klikke på en bestemt del af dokumentet som man ønsker at se. Hensigten med overbliksområdet er at st $\varnothing t t e$ navigation, samt at give læserne en fornemmelse af dokumentets indhold og struktur

\section{Eksperiments opbygning}

De 20 forsøgspersoner løste to slags opgaver: essay-opgaver og spørgsmålsopgaver. I essayopgaverne skulle fors $\varnothing$ gspersonerne læse et helt dokument. Derefter skulle de skrive et essay som fyldte en side og som beskrev indholdet af dokumentet. Desuden skulle de skrive en sides kommentarer om dokumentet. Efter at have skrevet essayet og kommentarerne skulle fors $\emptyset$ gspersonerne besvare seks spørgsmål som de ikke kendte ordlyden af mens de læste dokumentet. Intentionen med disse 'incidental learning' spørgsmål var at afdække dybden af fors $\varnothing$ gspersonernes læsning af dokumenterne. I spørgsmålsopgaver skulle fors $\emptyset$ gspersonerne besvare seks spørgsmål, et af gangen. Det var meningen at fors $\emptyset$ gspersonerne skulle lede i dokumenterne efter svaret. Dokumenterne som fors øgspersonerne læste var tidsskriftsartikler om objektorienteret systemudvikling på mellem 8 og 14 sider. Alle forsøgspersonerne gennemførte først en træningsopgave, som i gennemsnit varede 35 minutter. Derefter løste fors $\emptyset$ gspersonerne en essay-opgave og en spørgs- målsopgave. Dagen efter kom forsøgspersonerne tilbage og løste yderligere fire opgaver. Hvert par af en spørgsmålsopgave og en essayopgave blev løst med en af de tre grænseflader. I gennemsnit læste hver fors $\emptyset$ gsperson mere end fem timer. Alle fors $\emptyset$ gspersonerne var studerende på Datalogisk Institut. Til at analysere de opsamlede data brugte vi variansanalyse, som er beskrevet i Hornbæk \& Frøkjær (2001).

\section{Forskelle i brugsvenlighed}

For at vurdere brugergrænsefladens effektivitet gav vi svarene på opgaverne en karakter mellem 0 og 4. Karakteren 0 blev givet for det helt forkerte eller meget mangelfulde svar; karakteren 4 blev givet til den korrekte og meget velunderbyggede besvarelse. Mellem de tre grænseflader fandt vi en statistisk signifikant forskel i den karakter som forsøgspersonerne fik for besvarelsen af essayopgaver. Med overbliksgrænsefladen får forsøgspersonerne i gennemsnit en halv karakter mere end med den lineære og fiskeøjegrænsefladen. Vi fandt også en signifikant forskel mellem grænseflader i de 'incidental learning' spørgsmål som forsøgspersonerne fik efter at have skrevet essayet. Med fiskeøjegrænsefladen besvarer fors $\varnothing$ gspersonerne mellem 0.8 og 1.2 færre spørgsmål korrekt end med den lineære og overbliksgrænsefladen. Forsøgspersonernes tidsforbrug ved læsning af dokumenter som de skal skrive essays om er forskelligt mellem grænsefladerne: Fiske øjegrænsefladen er $16 \%$ hurtigere end overbliksgrænsefladen og den lineære grænseflade. Vi fandt ikke nogen forskel i karakter mellem grænsefladerne for spørgsmålsopgaver, men overbliksgrænsefladen er omkring $20 \%$ langsommere end den lineære grænseflade. Der er ikke nogle signifikante forskel mellem den lineære grænseflade og fiskeøjegrænsefladen. Nitten af fors øgspersonerne foretrak at bruge overblikgrænsefladen, en person foretrak den lineære grænseflade. Forsøgspersonerne nævnte som årsag til deres præference overblikket over dokumentstrukturen og at overbliksgrænsefladen st $\varnothing t t e d e$ navigation og gjorde det nemmere at finde rundt i dokumentet.

\section{Forskelle i laesevenlighed}

Ovenstående data belyser væsentlige forskelle i brugsvenlighed mellem grænsefladerne. Disse data fortæller os dog ikke hvordan fors $\varnothing$ gsperso- 
nerne læser dokumenterne eller hvordan de tre grænseflader st $\varnothing t$ ter fors $\varnothing$ gspersonerne $\mathrm{i}$ at navigere i dokumenterne. Under eksperimentet blev det automatisk registreret hvilke dele af artiklen forsøgspersonerne kunne se på et givent tidspunkt og hvordan de brugte mus og tastatur til at navigere igennem dokumentet. Derfor kan vi rekonstruere hvilke dele af dokumenterne forsøgspersonerne har kigget på, hvor lang tid de har kigget på forskellige dele, samt i hvilken rækkefølge de kiggede på dokumentets dele. Fra disse data kan vi vurdere hvordan de tre grænseflader påvirker læseprocessen.

For essayopgaverne fandt vi, at fors $\varnothing$ gspersonernes læsning af dokumenterne foregår i tre faser: en orienteringsfase, en lineær gennemlæsningsfase og en repetitionsfase. I orienteringsfasen navigerer fors $\emptyset$ gspersonerne gennem dokumentet, mens de særligt ser på artiklens abstrakt, introduktion og konklusion. I den lineære gennemlæsningsfase læser forsøgspersonerne gennem dokumentet fra begyndelsen til slutningen, ofte med hop fremad i dokumentet og regressioner til tidligere læste dele. I repetitionsfasen synes fors $\emptyset$ gspersonerne at genlæse det de opfatter som de vigtigste dele af artiklen. Figur 4 viser et eksempel på hvordan de tre faser kan se ud for en af fors $\emptyset$ gspersonerne et såkaldt læsemønster. Den vandrette akse i figuren viser den tid som er forløbet siden starten af opgaven. Den lodrette akse viser position i dokumentet. Linierne i figuren viser hvilken del af artiklen forsøgspersonen har kunnet se på et bestemt tidspunkt (mere præcist angiver hvert punkt i grafen den position i teksten som blev vist $\emptyset$ verst i tekstområdet i grænsefladen på et bestemt tidspunkt). Øverst i figuren er vist varigheden af de tre faser. Det interessante ved disse faser er at længden af dem varierer mellem de tre grænseflader. I fiske øjegrænsefladen bruger fors $\varnothing$ gspersonerne i gennemsnit ni minutter på at orientere sig indledningsvis. Dette er mere end dobbelt så meget som forsøgspersoner der bruger de to andre grænseflader. Til gengæld bruger forsøgspersonerne cirka en tredjedel mindre tid med fiske $ø$ jegrænsefladen $\mathrm{i}$ den lineære gennemlæsningsfase end med de andre grænseflader. Derved synes fiskeøjegrænsefladen at invitere til en mere overbliksorienteret læsestil - hvilket kan være grunden til at fors $\emptyset$ gspersonerne med denne grænseflade løser essayopgaverne hurtigere. Fiskeøjegrænsefladen støtter dermed visse typer opgaver, f.eks. relevansbedømmelse af dokumenter eller tidskritiske tilegnelsesopgaver, men støtter ikke lige så effektivt som de to andre grænseflader læsning for at opnå en fuld forståelse af et dokument.

Læsevenligheden i forbindelse med spørgsmålsopgaverne kan undersøges på tilsvarende måde. I spørgsmålsopgaverne kan svarene på spørgsmål findes på bestemte positioner, såkaldte svarpositi-

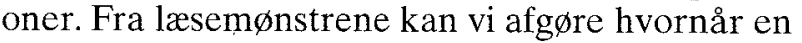
svarposition første gang ses og hvad forsøgspersonerne gør når de har fundet en svarposition. En tæt unders $\varnothing$ gelse af disse data viser to ting om læsevenlighed $\mathbf{i}$ grænsefladerne. For det første når fors øgspersonerne cirka lige hurtigt frem til en svarposition med de tre grænseflader. Det betyder at forskellen i tidsforbrug ikke kan skyldes at en af grænsefladerne ikke st øtter at finde et svar hurtigt. Til gengæld er det klart fra vores data at forsøgspersonerne med overbliksgrænsefladen cirka $40 \%$ hyppigere end i den lineære grænseflade navigerer væk fra en svarposition efter de har set et svar. Derved finder fors $\emptyset$ gspersoner som bruger overbliksgrænsefladen $30 \%$ flere svarpositioner i de artikler hvor svaret kan findes flere steder i artiklen. Overbliksgrænsefladen indbyder derved til udforskning af artikler og tilbyder åbenbart bekvemme måder at gøre dette på. Ulempen er at nogle læseprocesser måske er skrøbelige i den forstand at overbliksgrænsefladen vil distrahere læsere og lede dem til at miste fokus på den opgave de er ved at løse. Det højere tidsforbrug ved løsning af spørgsmålsopgaver kan måske skyldes at overbliksområdet i nogle situationer tiltrækker sig fors $\varnothing \mathrm{gspersonernes} \mathrm{opmærksomhed} \mathrm{og} \mathrm{derved}$ får dem til yderligere at udforske dokumentet, selvom de allerede har fundet et anvendeligt svar på opgaven de er ved at løse. 


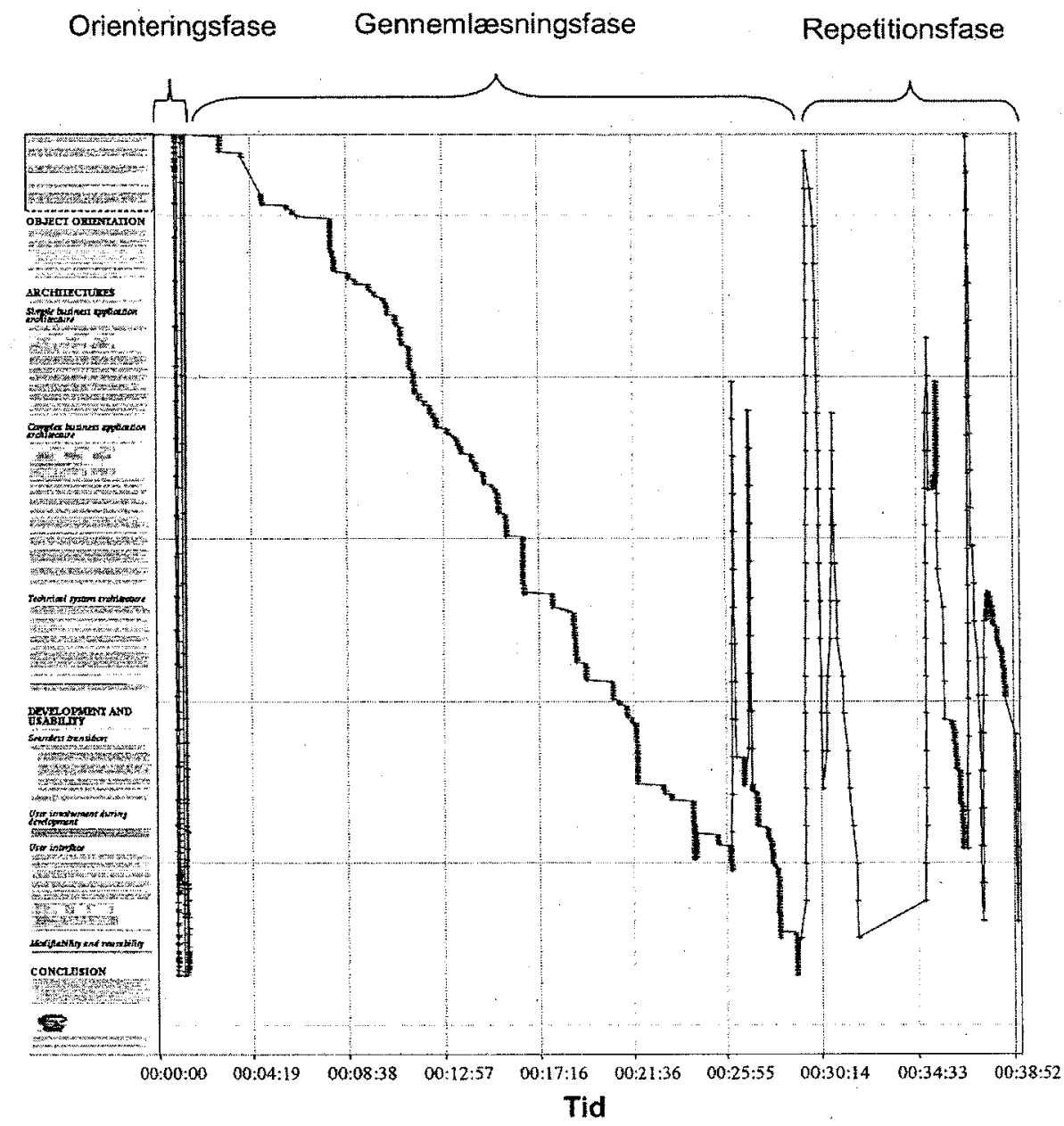

Figur 4. Lasemønstre for en assayopgave.

En anden interessant observation er, at fors $\varnothing$ gspersoner som anvender overbliksgrænsefladen mere hyppigt vender tilbage til tidligere sete svarposition end når de anvender de andre grænseflader. I stort omfang sker dette ved hjælp af overbliksområdet. En forklaring på denne adfærd er, at fors $\varnothing$ gspersonerne måske erindrer i hvilket område af dokumentet de fandt et særlig interessant tekstfragment. Fra forskning i papirdokumenter ved vi at læsere, uden at gøre sig det bevidst, erindrer hvor på siden de læste bestemt information (Rothkopf, 1971). Noget lignende er normalt sværere at gøre i elektroniske dokumenter, særligt når teksten er uden sidemarkeringer. Overbliksgrænsefladen støtter på den måde læsning ved at

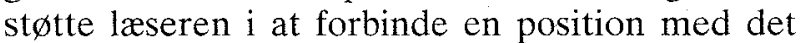
der læses.
Konklusion på undersøgelsen af visualisering af dokumenter

Ud fra vores eksperiment mener vi at overbliksgrænsefladen støtter fors $\varnothing$ gspersonerne bedre i at læse end de to andre grænseflader. Fors $\emptyset$ gspersonerne fik højere karakterer for deres essays. De foretrak også at læse ved hjælp af overbliksgrænsefladen og hævdede at de fik et bedre overblik over dokumentet. Desuden st $\varnothing$ ttes fors $\varnothing$ gspersonerne $i$ at huske tekstfragmenters position i dokumentet. Derfor mener vi at langt flere informationssøgesystemer burde anvende grænseflader som overbliksgrænsefladen og derved $\emptyset$ ge systemets læsevenlighed. Fiske øjegrænsefladen st $\varnothing t t e r$ fors $\varnothing$ gspersonerne i at læse hurtigt og støtter en overbliksorienteret læsestil. Nogle fors $\varnothing$ gspersoner var dog utrygge ved om vigtige afsnit af tek- 
sten var blevet formindsket. Desuden viser vores 'incidental learning' spørgsmål at forsøgspersonerne ikke får samme dybe forståelse af de dokumenter de læser som med de andre grænseflader. Fiskeøjegrænsefladen er derfor nyttig primært til tidskritiske opgaver. Vores eksperiment viser nytten af at undersøge læsning detaljeret. Først da vi kiggede på læsevenligheden af systemerne kunne vi forklare hvorfor vi observerede forskelle i brugsvenlighed. Desuden viser eksemplet, at det er muligt at forbedre læsevenligheden væsentligt for grænseflader til informationssøgesystemer.

\section{Konklusion}

Fra mit arbejde i menneske-datamaskine interaktion har jeg i denne artikel forsøgt at vise hvordan brugsvenlighed og læsevenlighed kan indgå i evaluering af informationss $\varnothing$ gesystemer. Brugsvenlighed giver fokus på hvor effektive, produktive og tilfredse brugere er når de søger information. Læsevenlighed vedrører tilegnelse af dokumenter og st $\varnothing t t e$ til navigation. Tilsammen giver de to begreber fokus på interaktiv informationssøgning, på design af velfungerende brugergrænseflader og på at relatere evaluering til brugeres faktiske gavn af informationssøgesystemer.

Jeg illustrerede nytten af begreberne brugs- og læsevenlighed ved to eksempler. Evalueringen af det tematiske kort viste hvordan almindeligt forekommende antagelser om værdien af tematiske kort ikke viser sig som forskelle $\mathrm{i}$ brugsvenlighed. Til gengæld afdækkede evalueringen en modsætning mellem den tid fors $\emptyset$ gspersonerne brugte på at søge og deres tilfredshed med systemerne. Kun fordi vi brugte en vifte af mål for brugsvenlighed kunne vi nå til en nogenlunde forståelse af gode og dårlige egenskaber ved tematiske kort. Eksperimentet med visualisering af dokumenter viser at det er muligt at fokusere på læseprocessen ved design og evaluering af informationssøgesystemer. Derved kunne overbliksgrænsefladen forbedre den karakter forsøgspersonerne opnåede for deres essays med cirka $25 \%$ - en markant forbedring ud fra et fokus på læsevenlighed. De to eksempler viser også nytten af at forstå forskelle i brugs- og læsevenlighed ved at se på hvordan brugere interagerer med informationss $\varnothing$ gesystemer. Kun ved at undersøge hvordan det tematiske kort

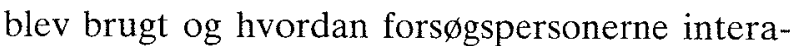
gerede med visualiseringer af dokumenter kan vi opstille forklaringer på hvorfor der er forskelle $\mathrm{i}$ brugs- og læsevenlighed. Tætte analyser af interaktion i eksemplerne har vist hvordan visuelle grænseflader kan lede brugeren til at udforske dokumenter og dokumentsamlinger unødigt - om dette er hensigtsmæssigt afhænger af hvilke opgaver informationssøgesystemet skal st $\varnothing$ tte. Desuden viste observationer og kommentarer fra forsøgspersonerne at de havde svært ved at forstå det tematiske kort og fiskeøjegrænsefladen, og at dette sænkede deres tilfredshed med systemerne. Graferne over faser i læseprocessen hjælper også til at forstå forskelle mellem grænsefladerne og forstå hvordan de støtter læsning og navigation i dokumenter.

Sammenfattende er min vigtigste pointe at brugergrænsefladen og interaktionen mellem mennesker og datamaskiner har afgørende indflydelse på informationssøgning. Mit forslag er derfor at fokusere på brugs- og læsevenlighed ved design og evaluering af informationss $\emptyset$ gesystemer.

\section{References}

Bishop, A. P. 1999. Document structure and digital libraries: how reseachers mobilize information in journal articles. Information Processing and Management, 35, 255-279.

Borg, I. \& Groenen, P. 1997. Multidimensional Scaling. Springer Verlag.

Bradow, R., Mitze, K., \& Rau, L. F. 1995. Automatic condensation of electronic publications by sentence selection. Information Processing \& Management, 31, 5, 675-685.

Byrne, M. D., John, B. E., Wehrle, N. S., \& Crow, D. C. 1999. The tangled web we wove: a taskonomy of WWW use. I Proceedings of the ACM Conference on Human Factors in Computing Systems (CHI '99, Pittsburgh PA, Maj 1999). ACM Press, New York, NY, 544-551.

Card, S. K., Mackinlay, J. D. \& Shneiderman, B. 1999. Readings in Information Visualization. San Francisco CA: Morgan Kaufmann. 
Chen, H., Houston, L., Sewell, R., \& Schatz, R. 1998. Internet browsing and searching: User evaluations of category map and concept space techniques. Journal of the American Society of Information Systems, 49, 7, 582-603.

Chin, J. P., Diehl, V. A., \& Norman, K. L. 1988. Development of an instrument for measuring user satisfaction of the human-computer interface. I Proceeding of the ACM Conference on Human Factors in Computing Systems (CHI '88, Washington, DC, Maj 1988). ACM Press, New York, NY, 213-218.

Dillon, A. 1994. Designing Usable Electronic Text. London: Taylor \& Francis.

Dumais, S. T. 1996. Interface Design for Information Retrieval. In Workshop on Social Aspects of Digital Libraries. Se http://is.gseis.ucla.edu/research/dl/dumais.html.

Frøkjær, E., Hertzum, M., \& Hornbæk, K.. Measuring usability: are effectiveness, efficiency, and satisfaction really correlated? I Proceeding of the ACM Conference on Human Factors in Computing Systems (CHI 2000, Haag, Holland, Maj 2000). ACM Press, New York, NY, 345-352.

Hearst, M. A. 1995. TileBars: visualization of term distribution information in full text information access. In . I Proceedings of the ACM Conference on Human Factors in Computing Systems (CHI '95, Denver CO, Maj 1995). ACM Press, New York, NY, 59-66.

Helms Jørgensen, A. 1990. Thinking-aloud in user interface design: a method promoting cognitive ergonomics. Ergonomics, 33, 4, 501-507.

Hersh, W. 1994. Relevance and Retrieval Evaluation: Perspectives from Medicine. Journal of the American Society for Information Science, 45, 3, 201-206.

Hornbæk, K. \& Frøkjær, E. 1999. Do Thematic Maps Improve Information Retrieval? In IFIP TC.13 International Conference on Human-Computer Interaction (INTERACT '99, Edinburgh, Scotland, August 1999). IOS Press, Amsterdam, 179-186.
Hornbæk, K. \& Frøkjær, E. 2001. Reading Electronic Documents: The Usability of Linear, Fisheye, and Overview+Detail Interfaces. In Proceedings of the ACM Conference on Human Factors in Computing Systems (CHI 2001, Seattle, WA, Marts 2000). ACM Press, New York, NY, 293-300.

ISO 1998. Ergonomic requirements for office work with visual display terminals (VDTs)-Part 11: Guidance on Usability.

Kengeri, R., Seals, C. D., Harley, H. D., Reddy, H. P., \& Fox, E. A. 1999. Usability study of digital libraries: ACM, IEEE-CS, NCSTRL, NDLTD. International Journal of Digital Libraries, 2, 157169.

Marchionini, G. 1992. Interfaces for End-User Information Seeking. Journal of the American Society for Information Science, 43, 2, 156-163.

Marchionini, G. and Komlodi, A. 1998. Design of Interfaces for Information Seeking. Annual Review of Information Science and Technology, 33, 89-130.

Rothkopf, E. 1971. Incidental memory for location of information in text. Journal of Verbal Learning and Verbal Behaviour, 10, 608-613.

Salton, G. \& McGill, M. 1983. Introduction to Modern Information Retrieval. McGraw-Hill.

Schriver, K. 1997. Dynamics in Document Presentation. New York/London: John Wiley \& Sons.

Sellen, A. \& Harper, R. Paper as an analytic resource for the design of new technologies. I Proceeding of the ACM Conference on Human Factors in Computing Systems (CHI'97, Atlanta GA, Marts 1997). ACM Press, New York, NY. 319-326,

Shneiderman, B. 1998. Designing the User Interface. 3. udgave. Reading, MA: Addison-Wesley.

Young, D. \& Shneiderman, B. 1993. A Graphical Filter/Flow Representation of Boolean Queries: A Prototype Implementation and Evaluation. Journal of the American Society of Information Systems, 44, 6, 327-339. 